\title{
Crystal optical method for temperature measuring
}

\author{
M.O.Romanyuk ${ }^{1}$, B.Andriyevsky ${ }^{1}$, O.Kostetsky ${ }^{2}$, \\ M.M.Romanyuk ${ }^{3}$, V.Stadnyk ${ }^{1}$ \\ 1 The Ivan Franko National University of Lviv, \\ 8 Kyryla i Mefodiya Str., 79005 Lviv, Ukraine \\ 2 Lviv State Agrarian University, 80381 Dublyany, Ukraine \\ 3 The National University "Lviv Politekhnika", \\ 12 Stepana Bandery Str., 79013 Lviv, Ukraine
}

Received August 7, 2001

\begin{abstract}
A new crystal optical method for temperature measuring based on the sign inversion of birefringence $\Delta n$ and temperature dependence of $\Delta n(T)$ is substantiated. The respective characteristics of some crystals are presented, which confirm good metrological and exploitation properties of the method. It is noted that the method solves some problems which arise in thermometry based on thermoelectricity and thermoresistance. The proposed method also gives better possibilities for measuring the temperature in hard conditions (in the region of high electric and magnetic fields, rotating workpieces etc.).
\end{abstract}

Key words: temperature, inversion of birefringence sign, scale of temperature

PACS: 78.20.Nv, 07.20.Dt

\section{General statements}

Some physical laws are used for assigning and measuring a temperature as well as for creating the reference temperature points [1]. Thermodetectors based on thermoelectricity and on thermoresistance are the most prevalent $[2,3]$. They need separate calibration and periodical verification of its stability. It is important to ensure that the magnitude of the electric current or the voltage detected have a single temperature origin. All these peculiarities are connected with diffusion of components in the contacts of two melted metals of a thermocouple, impurities in thermoresistance, and the change of crystalline structure of active elements of the sensor.

This leads to the idea of a thermocouple based on single crystals [4], substitution or improvement of the galvanic connection of sensor with the indicator, and creating a sensor with the intrinsic reference point of temperature [5]. The latter purpose is 
achieved through the use of a special headpiece on a thermocouple of certain metal, the temperature of which determines the reference temperature point in which the rate of increase or decrease of temperature is changed at the constant power of the heater or the cooler. Another metal of a headpiece is needed to obtain a different reference point.

Galvanic connections can be avoided using the optical sensors of temperature. One of this type of sensors is the optical scattering cell [6] filled with liquid and glass powder. This liquid and powder differ by the magnitude of refractive indices, its temperature and spectral dependence. When these refractive indices differ, the cell scatters the incident light strongly. When a crossing of the refractive index dispersions $n_{i}(\lambda)(i=1,2)$ takes place, the cell medium becomes optically homogeneous for a certain wavelength, and thereby the light scattering decreases. This peculiarity shows the magnitude of temperature.

The proposed method of defining and measuring the temperature is based on the sign inversion of birefringence $\Delta n$ of optically biaxial crystals [7]. This makes it possible to satisfy the above mentioned requirements of thermometry that arise based on thermoelectromotion and thermoresistance. In the proposed method a single crystal of good optical quality plays a role of the sensor, the point of birefringence inversion appears as an internal reference point, and the laser light beam ensures optical connection between the sensor and the indicator (screen or photodetector in the region of interference pattern). In this case the respective temperature point is fixed based on the interference pattern form or on the photocurrent minimum . This is the positive and clear peculiarity of the method. In such a way, having a set of monochromatic light sources one can fix different temperature points. When a single light source is presented (laser, for instance), then the deviation of temperature $\left(T-T_{i}\right)$ from the point of sign inversion of birefringence can be determined based on temperature changes of birefringence $\Delta n\left(T-T_{i}\right)$ (optical path difference $\Delta=d \cdot \Delta n$ ) of the same sensor measured in the direction of sign inversion of birefringence. The latter value can be determined using the known methods [6].

\section{Sign inversion of birefringence}

Several dozens of crystals are known today in which the curves of spectral dependences $n_{i}(\lambda)(i=1,2)$ cross one another in the point $\lambda_{0}$. The symmetry of optical indicatrix increases and the sign of birefringence for the respective direction of light propagation is changed in this point. In the case of optically uniaxial crystals such a point is called an isotropic one and a crystal becomes optically isotropic. The change of birefringence sign can be determined using only appropriate compensators. An optically biaxial crystal becomes optically uniaxial in this point, so one deals with an isotropic direction and this point can be seen through the appearance of a conoscopic pattern, characteristic of the cut of optically uniaxial crystal perpendicular to the optical axis. The change of a corresponding sign can be seen by the change of spatial orientation of the plane of the optical axes by $90^{\circ}$ of optically biaxial states of the crystal [6]. 


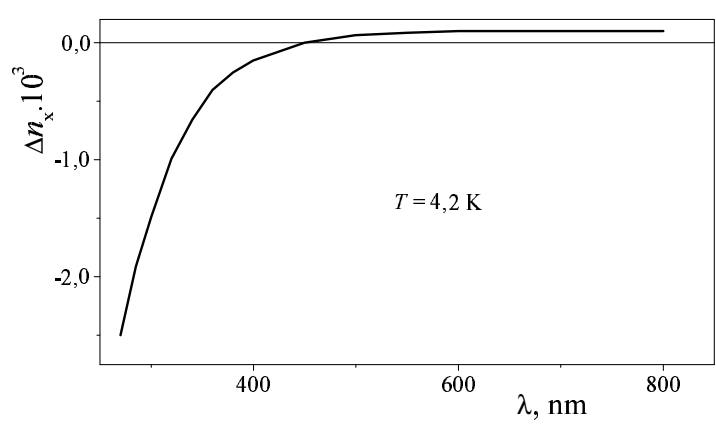

Figure 1. Spectral dependence of birefringence $\Delta n_{x}(\lambda)$ of deuterated Rochelle salt crystal at the temperature $4.2 \mathrm{~K}$.

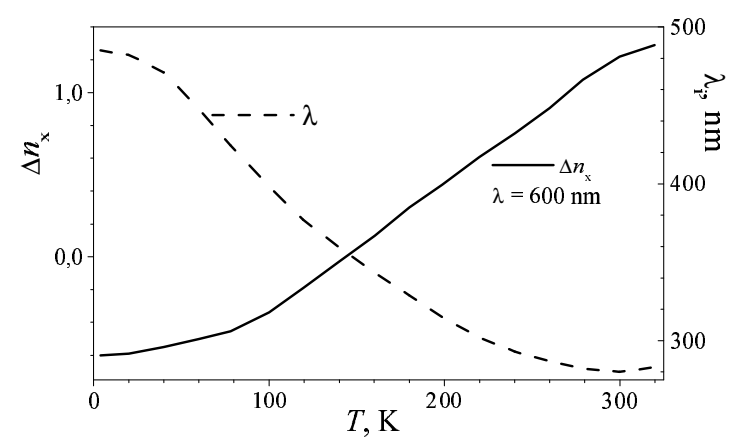

Figure 2. Temperature dependences of the birefringence $\Delta n_{x}(T)$ for light wavelength $\lambda=600 \mathrm{~nm}$ and the wavelength of sign inversion of birefringence $\lambda_{i}(T)$ for deuterated Rochelle salt crystal.

Spectral inversion of the sign of birefringence (SISB) in crystals has been studied by several authors [8-10]. Several dozens of crystals are known at present which possess this property, and thus the temperature and baric shifts of this point are determined.

Figures 1 and 2 show spectral (figure 1) and temperature (figure 2) dependences of birefringence $\Delta n_{x}$ and the wavelength of sign inversion of birefringence $\lambda_{i}$ for deuterated Rochelle salt crystal [11]. Points of the dotted curve correspond to a conoscopic pattern characteristic of the uniaxial crystal for the cut perpendicular to the optical axes. Analogous dependences for a set of other crystals are presented in [12]. General information about some of these crystals is presented in table 1.

Analytically, SISB can be described based on the multioscillator Selmeier dispersion formula. This way, the factors determinative for the spectral-and-temperature dependence of the isotropic state can be determined. So far there is no microscopic theory of this phenomenon.

Temperature sensitivity of the spectral position of the isotropic state depends upon spectral and temperature dependence of birefringence $\Delta n$ which can be easily determined in the experiment:

$$
\frac{\partial \lambda_{0}}{\partial T}=-\left(\frac{\partial \Delta n}{\partial T}\right) /\left(\frac{\partial \Delta n}{\partial \lambda}\right)
$$

This relation is important from practical viewpoint.

\section{Principles of crystal-and-optical thermometer based on the inversion of sign of birefringence}

The use of ISB for measuring the temperature and for creating the reference temperature points has been proposed in [13]. 




Figure 3. Scheme of the crystal optical thermometer based on the ISB (a) and the method of identification of temperature for a given wavelength $\lambda$ (b). $I_{0}, I-$ intensities of light; P, A - polarizers; C - crystal optical sensor of temperature; $\mathrm{V}$ - volume of measured temperature; $\mathrm{S}$ - screen with a hole in its middle; D photodetector.

The plane parallel plate of a transparent optically biaxial crystal with ISB point cut perpendicularly to the acute bisectrix between optical axes acts here as a sensor of temperature. The entering plane of a plate is mat, and the exit plane is polished. This plate is placed in a zone of measuring the temperature by diagonal manner relating the directions of light polarization in crossed light polarizers. It is placed in this zone perpendicularly to the laser beam, and two mutually perpendicular directions of light polarization in this crystalline plate are rotated by the angle of $45^{\circ}$ relating the other two mutually perpendicular directions of light polarization in the polarizer and in the analyzer. In this case, the object detected is an interference conoscopic pattern or an electric signal of the photodetector (figure 3).

A signal of the photodetector is determined by the intensity $I$ of an exit light according to the known relation,

$$
I=I_{0} \sin ^{2} 2 \alpha \sin ^{2} \frac{\pi d\left(n^{\prime}-n^{\prime \prime}\right)}{\lambda}
$$

where $I_{0}, \alpha, d,\left(n^{\prime}-n^{\prime \prime}\right), \lambda$ are the intensity of the incident light, the angle between the directions of light polarization in the crystal and in the polarizers, the thickness of the sample in the direction of the light beam, corresponding to birefringence, wavelength, respectively. It is obvious that the best arrangement corresponds to the case $\alpha=45^{\circ}$.

Sensitivity of the method is determined by the parameters of the sensor and the receiving apparatus and is placed in the range of $10^{-1}-10^{-3} \mathrm{~K}$. For instance, in the case of $\delta I \sim 0.01 I_{0}, d=0.1 \mathrm{~cm}, \partial \Delta n / \partial T \sim 5 \cdot 10^{-5} \mathrm{~K}^{-1}, \lambda=600 \mathrm{~nm}$ the inaccuracy of temperature determination is $\delta T \approx 2 \cdot 10^{-2} \mathrm{~K}$. 
Table 1. Characteristics of the temperature-and-spectral diagrams of the inversion of sign of birefringence (ISB) for several crystals [14].

\begin{tabular}{|c|c|c|c|c|c|}
\hline \multirow[t]{2}{*}{$\begin{array}{l}\text { Crystal, } \\
\text { cut }\end{array}$} & \multicolumn{2}{|c|}{$\begin{array}{l}\text { Ranges of the exis- } \\
\text { tence of ISB }\end{array}$} & \multicolumn{2}{|c|}{$\begin{array}{l}\text { Temperature sen- } \\
\text { sitivity of spectr- } \\
\text { al position of the } \\
\text { ISP } \\
\partial \lambda_{0} / \partial T, \mathrm{~nm} / \mathrm{K}\end{array}$} & \multirow[t]{2}{*}{$\begin{array}{l}\text { Temperature } \\
\text { range, } \mathrm{K} \\
\text { Spectral } \\
\text { range, nm }\end{array}$} \\
\hline & $\Delta \lambda, \mathrm{nm}$ & $\Delta T, \mathrm{~K}$ & averaged & maximal & \\
\hline $\begin{array}{l}\mathrm{KNaC}_{4} \mathrm{H}_{4} \mathrm{O}_{6} \cdot 4 \mathrm{H}_{2} \mathrm{O} \\
X\end{array}$ & $465-280$ & $4.2-330$ & -0.56 & -0.8 & $\begin{array}{l}20-250 \\
295-465\end{array}$ \\
\hline $\begin{array}{l}\mathrm{KNaC}_{4} \mathrm{H}_{4} \mathrm{O}_{6} \cdot 4 \mathrm{D}_{2} \mathrm{O} \\
X\end{array}$ & $463-279$ & $4.2-330$ & -0.57 & -0.8 & $\begin{array}{l}20-250 \\
295-465\end{array}$ \\
\hline $\begin{array}{l}\mathrm{NH}_{4} \mathrm{NaC}_{4} \mathrm{H}_{4} \mathrm{O}_{6} \cdot 4 \mathrm{H}_{2} \mathrm{O} \\
Z\end{array}$ & $1200-380$ & $130-330$ & -4.1 & $\begin{array}{l}-14 \\
\end{array}$ & $\begin{array}{l}130-180 \\
500-1200\end{array}$ \\
\hline $\begin{array}{l}\mathrm{NH}_{4} \mathrm{NaC}_{4} \mathrm{H}_{4} \mathrm{O}_{6} \cdot 4 \mathrm{H}_{2} \mathrm{O} \\
X\end{array}$ & $295-250$ & $4.2-95$ & -0.5 & $\begin{array}{l}-1.0 \\
\end{array}$ & $\begin{array}{l}20-95 \\
290-250\end{array}$ \\
\hline $\begin{array}{l}\mathrm{K}_{2} \mathrm{Ca}\left(\mathrm{SO}_{4}\right)_{2} \cdot \mathrm{H}_{2} \mathrm{O} \\
X\end{array}$ & $1000-200$ & $270-470$ & -0.4 & -4.0 & $\begin{array}{l}270-470 \\
200-1000\end{array}$ \\
\hline $\begin{array}{l}\left(\mathrm{C}_{6} \mathrm{H}_{4}\right) \mathrm{COOHCOOK} \\
Z\end{array}$ & $500-350$ & $4.2-560$ & -0.26 & -0.29 & $\begin{array}{l}50-560 \\
350-500\end{array}$ \\
\hline $\mathrm{Rb}_{2} \mathrm{SO}_{4}, Y$ & $1100-250$ & $72-160$ & -10 & -80 & $500-1100$ \\
\hline$X$ & $1100-300$ & $270-350$ & -10 & -20 & $500-1100$ \\
\hline $\mathrm{K}_{2} \mathrm{SO}_{4}, Y$ & $850-250$ & 617 & $\infty$ & $\infty$ & $850-250$ \\
\hline$X$ & $850-250$ & 700 & & & $850-250$ \\
\hline $\mathrm{LiKSO}_{4}, Z$ & $360-240$ & $180-420$ & -0.5 & -0.8 & $\begin{array}{l}180-420 \\
240-360\end{array}$ \\
\hline$\left(\mathrm{NH}_{4}\right)_{2} \mathrm{BeF}_{4}, Y$ & $\begin{array}{l}1100-240 \\
1100-240\end{array}$ & $\begin{array}{l}76-78 \\
304-312\end{array}$ & -110 & $\begin{array}{l}\infty \\
\infty\end{array}$ & $\begin{array}{l}76-T_{\text {melt }} \\
400-1100 \\
312-T_{\text {melt }} \\
500\end{array}$ \\
\hline $\mathrm{LiNbO}_{3}, X$ & 600 & 1100 & & & \\
\hline
\end{tabular}




\section{Distinctive features of the method}

1. One crystalline sample can be used for installation of several reference temperature points by changing the wavelength of light at which the ISB takes place.

2. A reference temperature point can be found through the qualitative characteristic (minimum of photosignal) or through the form of conoscopic pattern, characteristic of the uniaxial crystal cut perpendicularly to the optical axis.

3. The degree of selective light absorption (by wavelength) of the intermediate surrounding does not influence the nongalvanic connection of sensors and the receiver. For instance, the latter influence takes place in the case of optical pirometry.

4. The proposed method enables us to measure the temperature of the rotating workpieces and the workpieces being under high electric voltage.

Drawbacks of the method:

1. Relatively high inertiality of the sensor is caused by low thermal conductivity of the sensitive dielectric crystal.

2. It is necessary to calibrate the sensor for different sensitive elements (as a secondary temperature sensor) and to align it with the laser light beam.

3. A necessity of using a set of monochromatic light sources (filters, monochromator, lasers).

\section{Combination of birefringence and inversion of sign of bire- fringence}

It is convenient to work with a single source of monochromatic light when measuring the temperature. In this case the point of ISB can be regarded as an internal reference temperature point and the change of temperature $\delta T$ can be estimated based on birefringence change $\delta \Delta n$. In this case one can use the crystals, for which the corresponding points of ISB are placed in inconvenient spectral regions. An idea of this method is clear from figure 4 . Taking into account the number of characteristic conoscopic patterns (lemniscates) and their orientation one can estimate the magnitude and the sign of deviation from the point of ISB for the wavelength of the light used. Extrema of photocurrent are registered by inversion counter, which is one of the possible versions of accounting a sign of the birefringence change [14]. Thus, the use of temperature-and-spectral dependence of ISB makes it possible to determine reference temperature points based the on light wavelength of interference conoscopic pattern. Combination of such a point for one wavelength with a change of birefringence for this wavelength enables us to measure the temperature simply in a wide range relating the point of ISB. 


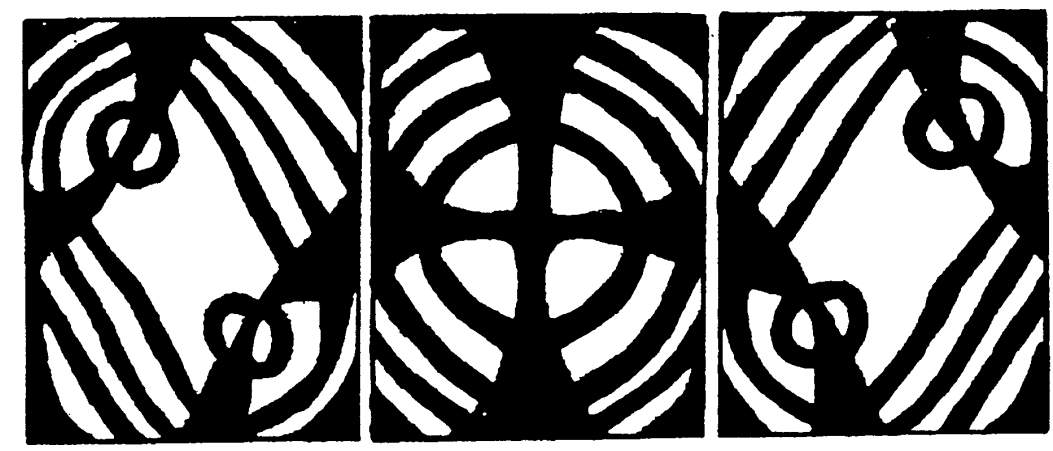

Figure 4. Conoscopic patterns for DRS crystal at the temperatures $T<T_{i}$ (left pattern), $T=T_{i}$ (middle pattern), and $T>T_{i}$ (rigth pattern) for the light propagation along $X$-axes $(\lambda=632.8 \mathrm{~nm}) . T_{i}$ is the temperature of sign birefringence inversion.

Crystalline sensor of temperature, internal reference point as ISB and optical connection of the sensor with the indicator create new possibilities for thermometry of special objects.

Authors are thankful to Corresponding Member Natl. Acad. Sci. of Ukraine Prof. I.V.Stasyuk, Prof. R.R.Levytsky, and Dr. A.P.Moina for stimulating interest to this paper and for useful discussions.

\section{References}

1. Kuinn T. Temperature. Moskow, Mir, 1985.

2. Gerashchenko O.A., Yeriomina A.N., Stadnik B.I. Temperature Measuring. Kyiv, Tekhnika, 1989.

3. Anatychuk L.M. Thermoelements and Thermoelectric Arrangements. Kyiv, Tekhnika, 1979.

4. Kuritnykh I.P., Burkhanov G.S., Stadnik B.I. Materials of High Temperature Thermometry. Moskow, 1986.

5. Sachenko A.A., Milchenko V.Yu., Kogan V.V. Measure of Temperature by Sensors with Build-in Calibrators. Moskow, 1986.

6. Chernyakova M.M., Steblyk V.A., Voitsekhov Yu.R. Devices for Measure of Temperature. Patent USSR, No. 402762. Information Bulletine, No. 2, 1973.

7. Romanyuk M.O. Crystal Optics. Kyiv, 1997.

8. Brodin M.S. Optical properties of single crystals CdS. // Solid State Physics, 1960, vol. 2, No. 9, p. 2152-2157.

9. Solovyov L.E., Rudakov V.S. Phenomena of pseudo crossing of dispersional curves. // Vesnik Leningradskogo universiteta. Fisika i khimiya, 1968, No. 4, p. 23-26.

10. Suslikov L.M., Khasitarchanov Yu.A., Gadmashi Z.P. Birefringence of uniaxially stressed crystals of $\mathrm{AgGaSe}_{2}$. // Solid State Physics, 1990, vol. 32, No. 2, p. 632634.

11. Gaba V.M., Romanyuk N.A., Franiv A.V. Properties of optical indicatrix of deuterated Rochelle salt crystals. // Ukr. J. Phys., 1982, vol. 27, No. 3, p. 333-338. 
12. Romanyuk M.O. Temperature-and-spectral diagrams of inversion of sign of birefringence and their possible applications. // Scientific Society of T.Shevchenko in Lviv. Physical collection, 1993, vol. 1, p. 291-303.

13. Romanyuk N.A., Kostetskii A.M. Method of measuring absolute temperature in transparent isotropic media. Patent USSR, No. 742725, 1980.

14. Romanyuk N.N., Romanyuk N.A., Kostetskii A.M. Polarization- and-optical device for reversible count of interference fringes. // Patent USSR, No. 1032329, Information Bulletine, No. 28, 1983.

\title{
Кристалооптичний метод вимірювання температури
}

\author{
М.О.Романюк ${ }^{1}$, Б.Андрієвський ${ }^{1}$, О.Костецький ${ }^{2}$, \\ М.М.Романюк ${ }^{3}$, В.Стадник ${ }^{1}$ \\ 1 Львівський національний університет ім. Івана Франка, \\ 79005 Львів, вул. Кирила і Мефодія, 8 \\ 2 Львівський державний аграрний університет, 80381 Дубляни \\ 3 Національний університет "Львівська політехніка", \\ 79013 Львів, вул. Степана Бандери, 12
}

\section{Отримано 7 серпня 2001 р.}

Обгрунтовується новий кристалооптичний метод вимірювання температури на базі інверсії знаку двозаломлення $\Delta n$ та температурної залежності $\Delta n(T)$. Наведено відповідні характеристики деяких кристалів, які підтверджують високі метрологічні та експлуатаційні характеристики методу. Відзначається, що метод розв'язує деякі проблеми, що виникають перед термометрією на базі термоелектрики і термоопору, а також відкриває більш високі можливості вимірювань температури у важких умовах (в області високих електричних та магнітних полів, деталей, що обертаються і ін.).

Ключові слова: температура, інверсія знаку двопроменезаломлення, шкала температури

PACS: $78.20 . N v, 07.20 . D t$ 